\title{
事を急ぐべきではない
}

\section{Not so fast}

\section{Nature Vol.433(557)/10 February 2005}

生物医学研究の新興国との共同研究を考えるのならば、相手国の生命倫理法制を事前に検証すべきである。

英国政府の視察団「グローバル・ウォッチ・ミッション」 は、昨年 9 月に中国、シンガポール、韓国を 2 週間か けて視察し、各国での幹細胞研究の現状について熱のこ もった報告書を作成した。この報告書に関するプレスリ リースが 1 月に発表され、これらの国々では「倫理基準 を英国モデルに近づける努力がなされている」とし、「英 国を本拠とする幹細胞研究機関の質の高さと国際的地位 を考慮すれば、英国と極東諸国との協力関係を樹立する 絶好の機会が到来していると言える」といった提言がな されていた。

準備完了ということらしい。でも、ちょっと考えが甘い のではないだろうか。

これらの国々では、最近になって、生命倫理に関する 国内法制が整備され、例えば韓国の生命倫理法はこの 1 月に施行されたばかりである (Nature 2005 年 1 月 20 日号 p.186 参照)。しかし法規の遵守と執行はなされて いるのだろうか。

視察団は、中国でトップクラスの研究所を数ヶ所訪れ ている (http://www.globalwatchonline.com/missions/ tmsmrep.aspx)。しかし、この視察団の報告から中国全 体についての一般論を導き出せるのだろうか。今回のプ レスリリースには、中国では「実験的な治療を医療現場 に導入することに対する抵抗感が西側諸国よりもかなり 薄い」と指摘されている一方で、「このことは、臨床研 究が倫理に反している、あるいは臨床研究への規制が十 分になされていないことを意味するものではない」とも 記されている。

しかし、すべてがうまくいっている兆候だと捉えるべ きでもない。中国では、インフォームドコンセントを得
ずに臨床試験が行われたり、患者の必死さに付け込んで 臨床試験が行われたりしているという話がある。中国に も生命倫理法制は存在しているが、それらが全国的にみ てどの程度遵守されているのかは別問題である。確かに、 このような臨床試験の多くに地方政府の高官が関与して いると言われている。地方政府が秘密裏に事を進めれば、 実際の発覚までにどれほどのことができるかを理解する には、多数の中国人が HIV に感染してしまった献血ス キャンダルを思い起こせば十分である。

生命倫理法制に問題のある国との共同研究を考えるの であれば、事前調査を行うべきである。中国を訪れた英 国政府の視察団は、インフォームドコンセントの書式を 調査するのが非常に難しかったという。2004 年にかの 有名なクローニング実験を行った韓国の研究者も、実験 に用いたインフォームドコンセントの書式の提出を拒み 続けた経緯がある (Nature 2004 年 5 月 6 日号 p.3 参照)。 これらは危険なサインだ。

中国では政策を駆使して法令遵守の確実な達成を目指 しているが、これと同じように、新たな生命倫理法制に よって、研究者は法令を遵守するようになるかもしれな

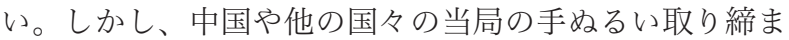
りに付け込む研究者も現れるだろう。そうやってうまく 逃げ切ってしまう研究者も出てくるだろうし、研究プロ ジェクトが失敗してキャリアを台無しにする研究者も出 ることだろう。 